towns, with an estimated population of $8,344,329$, the deathrate was 27.4. Deaths reported 4393 : under five 2146 ; pulmonary consumption 656 , acute diseases of the respiratory organs 511, diphtheria and croup 241, scarlet fever 101, whooping-cough 61 , typhoid fever 49 , measles and rötheln 38 , puerperal fever 23, stmall-pox (Dortmund, Essen eight) nine, typhus fever (Danzig, Posen) two. The death-rates ranged from 14.6 in Stettin to 42.9 in Augsbúrg ; Königsberg 29.1; Breslau 37.8; Munich 41.9; Dresden 25.9; Berlin 26.2; Leipzig 27.3; Hamburg 27.2 ; Hanover 20; Bremen 19; Cologne 26.2 ; Frankfort 28.5; Strasburg 30.7.

In the 28 English towns, with an estimated population of $\mathbf{8 , 4 5 7 , 5 1 4}$, for the week ending March 25th, the death-rate was 23.7. Deaths reported 3842 : acute diseases of the respiratory organs (London) 427, whooping - cough 251 , moasles 162 , fever 65, scarlet fever 64 , diarrhoa 52 , diphtheria, 24, small-pox (London 13) 14. The death-rates ranged from 16.2 in Cardiff to 30.2 in Manchester; Leeds 19.3 ; Bristol 19.6; Liverpool 22.4 ; London 24.5; Sheffield 25.3.

For the week ending March 25th in the Swiss towns, population 479,934 , there were 49 deaths from acute diseases of the respiratory organs, pulmonary consumption 47 , diarrhœal diseases 18 , diphtheria and croup 15 , scarlet fever six, whooping-cough five, typhoid fever three, puerperal fever two. The death-rates were, Geneva 29.3; Zurich 34.3; Basle 27.7; Berne 32.2.

The meteorological record for the week ending April 8th in Boston, was as follows, according to observations furnished by Sergt. O. B. Cole, of the U. S. Signal Corps : -

\begin{tabular}{|c|c|c|c|c|c|c|c|c|c|c|c|c|c|c|c|c|c|c|c|}
\hline \multirow{2}{*}{$\begin{array}{l}\text { Date. } \\
\text { April, } \\
\text { 1882. }\end{array}$} & \multirow{2}{*}{$\begin{array}{c}\begin{array}{c}\text { Barom- } \\
\text { eter. }\end{array} \\
\text { ⿷匚⿱ 口⿸尸 }\end{array}$} & \multicolumn{3}{|c|}{$\begin{array}{l}\text { Thermom- } \\
\text {. eter. }\end{array}$} & \multicolumn{4}{|c|}{$\begin{array}{c}\text { Relative } \\
\text { Humidity. }\end{array}$} & \multicolumn{3}{|c|}{$\begin{array}{l}\text { Direction of } \\
\text { Wind. }\end{array}$} & \multicolumn{3}{|c|}{$\begin{array}{l}\text { Velocity of } \\
\text { Wind. }\end{array}$} & \multicolumn{3}{|c|}{$\begin{array}{l}\text { State of } \\
\text { Weather. }{ }^{1}\end{array}$} & \multicolumn{2}{|c|}{ Rainfall. } \\
\hline & & 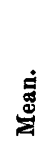 & 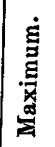 & 䔍 & 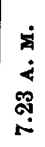 & 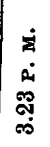 & 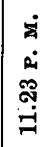 & 总 & $\begin{array}{l}\dot{\Sigma} \\
\dot{<} \\
\Re \\
\stackrel{\leftrightarrow}{*}\end{array}$ & 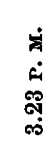 & 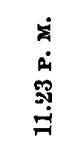 & 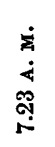 & 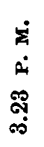 & 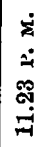 & 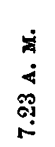 & 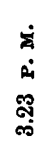 & 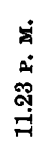 & 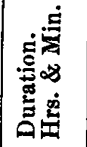 & 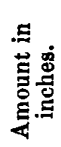 \\
\hline $\begin{array}{ll}\text { Sun., } & 2 \\
\text { Mon., } & 3 \\
\text { Tues., } & 4 \\
\text { Wed., } & 5 \\
\text { Thurs., } & 6 \\
\text { Fri., } & 7 \\
\text { Sat., } & 8\end{array}$ & \begin{tabular}{|l|}
29.931 \\
30.519 \\
30.118 \\
30.394 \\
30.518 \\
30.045 \\
30.104
\end{tabular} & $\begin{array}{l}49 \\
33 \\
49 \\
37 \\
35 \\
38 \\
43\end{array}$ & $\begin{array}{l}68 \\
39 \\
61 \\
53 \\
41 \\
49 \\
59\end{array}$ & $\begin{array}{r}37 \\
30 \\
28 \\
33 \\
29 \\
32 \\
-37\end{array}$ & $\begin{array}{l}93 \\
68 \\
61 \\
54 \\
61 \\
88 \\
68\end{array}$ & $\begin{array}{l}44 \\
48 \\
49 \\
51 \\
60 \\
83 \\
60\end{array}$ & \begin{tabular}{|c}
66 \\
73 \\
90 \\
60 \\
71 \\
100 \\
82
\end{tabular} & $\begin{array}{l}68 \\
63 \\
67 \\
55 \\
64 \\
90 \\
70\end{array}$ & $\begin{array}{l}\text { SW } \\
\text { NE } \\
\text { SW } \\
\text { NE } \\
\text { NE } \\
\text { SE } \\
\text { NW }\end{array}$ & $\begin{array}{c}\text { W } \\
\text { SE } \\
\text { SW } \\
\mathbf{E} \\
\mathbf{E} \\
\mathbf{W} \\
\mathbf{E}\end{array}$ & $\begin{array}{c}\text { NW } \\
\text { S } \\
\text { SW } \\
\text { SE } \\
\text { SE } \\
\text { W } \\
\text { SW }\end{array}$ & $\begin{array}{r}9 \\
4 \\
13 \\
16 \\
9 \\
8 \\
10\end{array}$ & $\begin{array}{r}25 \\
11 \\
20 \\
13 \\
19 \\
5 \\
11\end{array}$ & $\begin{array}{r}11 \\
6 \\
8 \\
3 \\
9 \\
8 \\
3\end{array}$ & $\begin{array}{l}\mathbf{O} \\
\mathbf{O} \\
\mathbf{F} \\
\mathbf{O} \\
\mathbf{C} \\
\mathbf{O} \\
\mathbf{C}\end{array}$ & $\begin{array}{l}\mathbf{F} \\
\mathbf{C} \\
\mathbf{O} \\
\mathbf{F} \\
\mathrm{O} \\
\mathrm{O} \\
\mathrm{C}\end{array}$ & $\begin{array}{l}\mathbf{C} \\
\mathbf{C} \\
\mathbf{R} \\
\mathbf{C} \\
\mathrm{O} \\
\mathrm{G} \\
\mathbf{C}\end{array}$ & $\begin{array}{l}= \\
\bar{z} \\
\bar{z}\end{array}$ & $\begin{array}{l}= \\
= \\
= \\
=\end{array}$ \\
\hline $\begin{array}{l}\text { Means, the } \\
\text { week. }\end{array}$ & 30.233 & 41 & 68 & 28 & & & & 68 & & & & & & & & & & 11.35 & . I1 \\
\hline
\end{tabular}

1 O., cloudy ; C., clear ; F., fair ; G., fog ; H., hazy ; S., snow ; R., rain ; T., threatening ; X., clearing.

\section{UNUSUAL RESULTS OF VACCINATION.}

Phenix, Mich., April 5, 1882.

Mr. Editor, - In your issue of March 23, 1882, there are detailed several cases of unusual results of vaccination. I herewith give you a much larger number of similar cases. Since January 1 st I have performed over 800 successful cases of primary vaccination, using nothing but bovine virus; among that number there have been 68 cases with an eruption of dusky red color, covering nearly the whole surface of the body. The eruption was slightly raised, somewhat resembling measles ; in fact, my attention was called to it by the parents thinking that the children had the measles. A few small vesicles scattered among the patches of eruption only could be seen. The patients all complained of an intense itching. I also performed 13 successful primary vaccinations with humanized virus one remove from the heifer, and among that number three had the above eruption. Among over 200 successful revaccinations I have not seen any eruption.

The eruption in the above cases passed away in a few days, leaving a brownish tinge of the skin where it had been, which also disappeared in a few days more. My brother practitioners in this neighborhood have had similar experiences this winter.

$$
\text { Yours truly, A. I. LawBadGh, M. D. }
$$

OFFICIAL LIST OF CHANGES OF STATIONS AND DUTIES OF OFFICERS OF THE MEDICAL DEPARTMENT U. S. ARMY, FROM APRIL 8, 1882, TO APRIL 14, 1882

Greenleaf, Charles R., major and surgeon. Relieved from duty in Department of Dakota, to proceed to New York city, and on arrival report by letter to the Surgeon-General. S. $O$. 78, A. G. O., April 5, 1882.

WoovhulL, A. A., major and surgeon. Now awaiting orders; to report in person to the commanding officer of the recruiting depot, David's Island, N. Y. H., for duty at that post. S. O. 78, C. S., A. G. O.

Williams, John W., major and surgeon. Relieved from duty in Department of the Missouri, to proceed to Washington, D. C., and report to the Surgeon-General. S. O. 78, C. S., A. G. 0 .

WATERs, W. E., major and surgeon. Relieved from duty in Department of Texas, to proceed to Washington, D. C., and report to the Surgeon-General. S. 0. 78, C. S., A. G. O.
JAQUETT, G. P., major and surgeon. Relieved from duty at David's Island, N. Y. H., to proceed to his home and report by letter to the Surgeon-General. S. O. 78, C. S., A. G. O.

Brown, J. M., major and surgeon. Relieved from duty in Department of the Missouri, to proceed to Cincinnati, Ohio, and on arrival report by letter to the Surgeon-General. $S$. $O$. 78, C. S., A. G. O.

Cleary, P. J. A., captain and assistant surgeon. Relieved from duty in Department of the East, and, on expiration of his present sick leave of absence, to report by letter to the SurgeonGeneral. S. 0. 78, C. S., A. G.

Cronkhite, H. M., captain and assistant surgeon. Granted leave of absence for four months from June 1, 1882. S. 0.80 , C. S., A. G. O.

Carvallo, Carlos, captain and assistant surgeon. The extension of his leave of absence on surgeon's certificate of disability granted him in S. O. 256, November 12, 1881, from A. $G$. $O$., is still further extended six months on account of sickness. S. 0. 80, A. G. O., April 7, 1882.

Byrne, Charles B., captain and assistant surgeon (Fort Barrancas, Fla.). Assigned to temporary duty at Mt. Vernon Barracks, Ala., during absence of Assistant Surgeon Cunningham. S. O.41, Department of the South, April 12, 1882.

FinLeY, captain and assistant surgeon. Having reported at these headquarters, is assigned to duty at Fort Concho, Texas. S. O. 35, Department of 'Texas, April 8, 1882.

Moseley, E. B., captain and assistant surgeon. Relieved from duty in Department of the Platte, to proceed to New York city, and, on arrival, report by letter to the Surgeon-General. S. O. 78, C. S., A. G. O.

MAUS, L. M., captain and assistant surgeon. Relieved from duty at David's Island, N. Y. H., and to report in person to the commanding general, Department of the Missouri, for assignment to duty. S. 0. 78, C. S., A. G. O.

KILBOURNE, H. S., captain and assistant surgeon. Relieved from duty in Department of the East, and to report in person to the commanding general, Department of Dakota, for assignment to duty. S. O. 78, C. S., A. G. O.

TAYLOR, M. E., captain and assistant surgeon. Relieved from duty in Department of the Missouri, to proceed to St. Lonis, Mo., and, on arrival, report by letter to the Surgeon-General. S. 0. 78 , C. S., A. G. O.

SPENCER, WM. G.. captain and assistant surgeon. Granted leave of absence for four months, with permission to apply for an extension of two months. S. O. 80, C. S., A. G. O. 